\title{
Methane Steam Reforming over an Ni-YSZ Solid Oxide Fuel Cell Anode in Stack Configuration
}

\author{
D. Mogensen, ${ }^{1}$ J.-D. Grunwaldt, ${ }^{1,2}$ P. V. Hendriksen, ${ }^{3}$ J. U. Nielsen, ${ }^{4}$ and K. Dam-Johansen ${ }^{1}$ \\ ${ }^{1}$ Department of Chemical and Biochemical Engineering, Technical University of Denmark, Soltofts Plads Building 229, \\ 2800 Kongens Lyngby, Denmark \\ ${ }^{2}$ Institute for Chemical Technology and Polymer Chemistry, Karlsruhe Institute of Technology (KIT), \\ Engesserstraße 20, 76131 Karlsruhe, Germany \\ ${ }^{3}$ Department of Energy Conversion and Storage, Technical University of Denmark, DTU Risoe Campus, Frederiksborgvej 399, \\ 4000 Roskilde, Denmark \\ ${ }^{4}$ Topsoe Fuel Cell, Nymøllevej 66, 2800 Kongens Lyngby, Denmark
}

Correspondence should be addressed to D. Mogensen; damogen@gmail.com

Received 17 February 2014; Accepted 20 April 2014; Published 24 June 2014

Academic Editor: Subrata Mondal

Copyright (C) 2014 D. Mogensen et al. This is an open access article distributed under the Creative Commons Attribution License, which permits unrestricted use, distribution, and reproduction in any medium, provided the original work is properly cited.

\begin{abstract}
The kinetics of catalytic steam reforming of methane over an Ni-YSZ anode of a solid oxide fuel cell (SOFC) have been investigated with the cell placed in a stack configuration. In order to decrease the degree of conversion, a single cell stack with reduced area was used. Measurements were performed in the temperature range $600-800^{\circ} \mathrm{C}$ and the partial pressures of all reactants and products were varied. The obtained rates could be well fitted with a power law expression $\left(r \propto P_{\mathrm{CH}_{4}}^{0.7}\right)$. A simple model is presented which is capable of predicting the methane conversion in a stack configuration from intrinsic kinetics of the anode support material. The predictions are compared with the stack measurements presented here, and good agreement is observed.
\end{abstract}

\section{Introduction}

The major advantage of partial internal steam reforming in an SOFC is that the waste heat from the electrochemical reactions and the joule heat are used to supply the energy for the endothermic reforming reaction (Reaction (1)) which has a reaction enthalpy of $206 \mathrm{~kJ} / \mathrm{mol}$ at $25^{\circ} \mathrm{C}$. The overall reaction is still strongly endothermic when taking into account also the exothermic water gas shift reaction (Reaction (2)) having a reaction enthalpy of $-41 \mathrm{~kJ} / \mathrm{mol}$ at $25^{\circ} \mathrm{C}[1]$

$$
\begin{aligned}
& \mathrm{CH}_{4}+\mathrm{H}_{2} \mathrm{O} \rightleftharpoons 3 \mathrm{H}_{2}+\mathrm{CO} \\
& \mathrm{CO}+\mathrm{H}_{2} \mathrm{O} \rightleftharpoons \mathrm{CO}_{2}+\mathrm{H}_{2}
\end{aligned}
$$

A further advantage of internal reforming is the decreased need for cooling via air flow at the cathode side, which can significantly increase system efficiency.

The rate of catalytic steam reforming of methane over an industrial SOFC anode is very high [2]. This is caused by the combined effect of high operating temperature, a highly active catalyst material, and a high nickel catalyst content. The Ni content and particle size are optimised to meet electrochemical and electrical needs and not for optimizing the steam reforming rate. The result is a rapid cooling, due to the reaction enthalpy, at the anode inlet giving large temperature gradients which decreases the stack efficiency and in the worst case can result in mechanical failure of the cells, due to thermal stresses [3]. So in order to achieve optimal operation of SOFC systems with internal steam reforming, it is necessary to have a good understanding and possibly control the amount reforming taking place in the cell. This in turn requires a good model representation of the stack, which has also received much attention lately [4-11]. The accuracy of such models depends on the accuracy of the kinetic expression used to predict the steam reforming rate and the purpose of this work is to obtain such an expression measured directly in a stack configuration. Furthermore, it is highly advantageous to be able to predict the reforming rate in 
different stack configurations. In rigorous models describing both the flow in the gas channels and the diffusion through the anode, the observed reforming rate can be predicted by using an intrinsic kinetic expression. Such a model will however require heavy computations if used at stack level. In Section 4 a very simple method for predicting the reforming rate in a stack is presented and validated.

\section{Experimental}

The setup used in these investigations is an "Evaluator C50" from FuelCon [12], which has undergone some modifications to fit the purpose of these experiments. Dry gas flows are controlled with mass flow controllers (MFC) of the type "LOW $\triangle P$ FLOW" and "EL-FLOW" from Bronkhorst HI-TEC, which were calibrated using a Gilibrator 2 soap bubble flow meter from Gilian with a specified measuring range of 20$6000 \mathrm{~mL} / \mathrm{min}$. Water vapour is added by bubbling nitrogen through a bubble flask at $90^{\circ} \mathrm{C}$. Temperature measurements were made with $\mathrm{K}$-type thermocouples.

Two IR analyzers of the type NGA 2000 Analyzer from Fisher-Rosemount were used interchangeably to measure the $\mathrm{CO}$ and $\mathrm{CO}_{2}$ content in the gas streams. The contents of the remaining species were calculated from the mass balance. The fact that this is a trustworthy method was verified in some selected cases where a gas chromatograph was used to determine the concentration of all species (except $\mathrm{H}_{2} \mathrm{O}$ ) present at both inlet and outlet $\left(\mathrm{CH}_{4}, \mathrm{CO}_{2}, \mathrm{CO}\right.$, and $\left.\mathrm{H}_{2}\right)$. The analyzers have a measurement error of $1 \%$ of the given measuring limit.

The stacks were reduced by the following procedure: heating to $860^{\circ} \mathrm{C}$ in $\mathrm{N}_{2}$. At $860^{\circ} \mathrm{C}$ the gas was changed to $20 \% \mathrm{H}_{2}$ in $\mathrm{N}_{2}$ for at least 4 hours; hereafter the sample was cooled to the test temperature and measurements were started.

The first attempt of measuring the steam reforming kinetics was made on a 5-cell SOFC $10 \mathrm{~cm} \times 10 \mathrm{~cm}$ standard stack from Topsoe Fuel Cell. It was found that the methane was completely converted, even at the highest flows that the setup could deliver.

Therefore a special stack was provided by Topsoe Fuel Cell, with only a single crossflow cell. Three quarters of the cell was cut away so that a number of the cathode flow channels were removed, and the length of the anode flow channels was shortened, as illustrated in Figure 1.

A further decrease in cell area would have been preferred, but removing part of the cell significantly reduced the robustness of the cells, and several modified cells cracked under conditions that a normal stack could easily withstand. Furthermore, removing more than $3 / 4$ of the cell could result in a gas flow pattern significantly different from that of the full cell.

Four thermocouples were placed in the gas distribution plates close to the flow channels, in order to monitor the temperature gradient: one at each corner of the fuel inlet side, one at the corner with fuel outlet and air inlet, and finally one at the fuel outlet and halfway through the air channel. The temperature used in later calculations is an average of these four measurements. The cathode side was only fed with

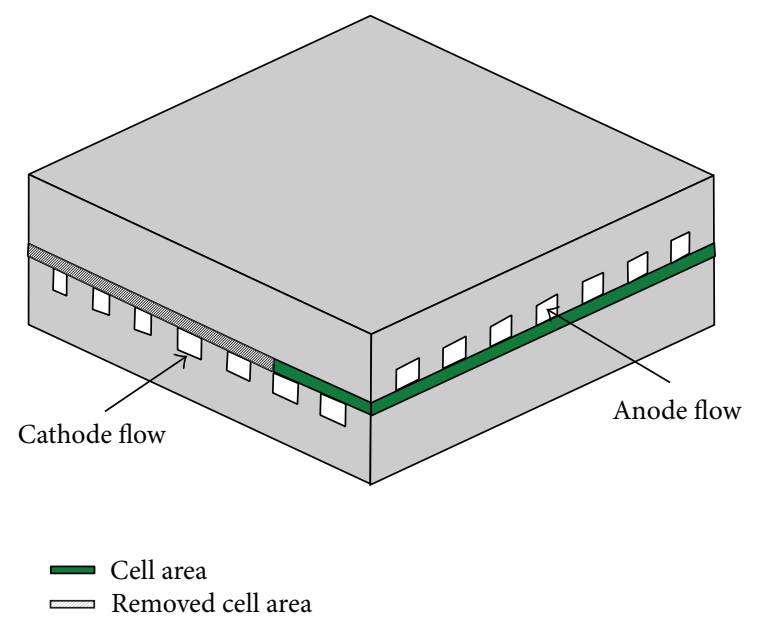

FIGURE 1: Illustration of the orientation of the quarter cell with respect to flow directions.

TABLE 1: Overview of the gas composition at standard conditions and the range each gas is varied in.

\begin{tabular}{lcc}
\hline Gas & $\begin{array}{c}\text { Standard } \\
\mathrm{kPa}\end{array}$ & $\begin{array}{c}\text { Range } \\
\mathrm{kPa}\end{array}$ \\
\hline $\mathrm{CH}_{4}$ & 12 & $12-30$ \\
$\mathrm{H}_{2} \mathrm{O}$ & 56 & $45-70$ \\
$\mathrm{H}_{2}$ & 7 & $7-18$ \\
$\mathrm{CO}$ & 0 & $0-6$ \\
$\mathrm{CO}_{2}$ & 0 & $0-9$ \\
\hline
\end{tabular}

nitrogen, both in order to avoid mixing of air with the anode gas and to avoid electrochemical reactions in the cell. It is desired to avoid the electrochemical reactions, since the steam reforming reaction can be studied better, when no other reactions are taking place.

The rate measurements on this cell were performed at flows, much higher than what is used during normal operation of an SOFC, with a total flow of approximately $2 \mathrm{Nl} / \mathrm{min}$ and a methane flow of up to $0.5 \mathrm{Nl} / \mathrm{min}$. This was done in order to decrease the degree of conversion of methane. The supplied methane flow is enough to sustain a current of $70 \mathrm{~A}$ which corresponds to a current density of $3 \mathrm{~A} / \mathrm{cm}^{2}$. The specific current density where the SOFC is expected to operate depends on the specific application as well as on the area specific resistance. Normal current densities applied in long-term durability testing of SOFC, at the present development stage, lie in the range between $0.25 \mathrm{~A} / \mathrm{cm}^{2}$ and $1 \mathrm{~A} / \mathrm{cm}^{2}$. The pressure and temperature were $T=600-700^{\circ} \mathrm{C}$ and $P=1.1-1.25 \mathrm{~atm}$.

Table 1 shows the standard gas composition as well as the range in which each gas species was varied in the inlet.

\section{Results}

During the rate measurements it was observed that the catalytic activity of the anode had a slow approach to 


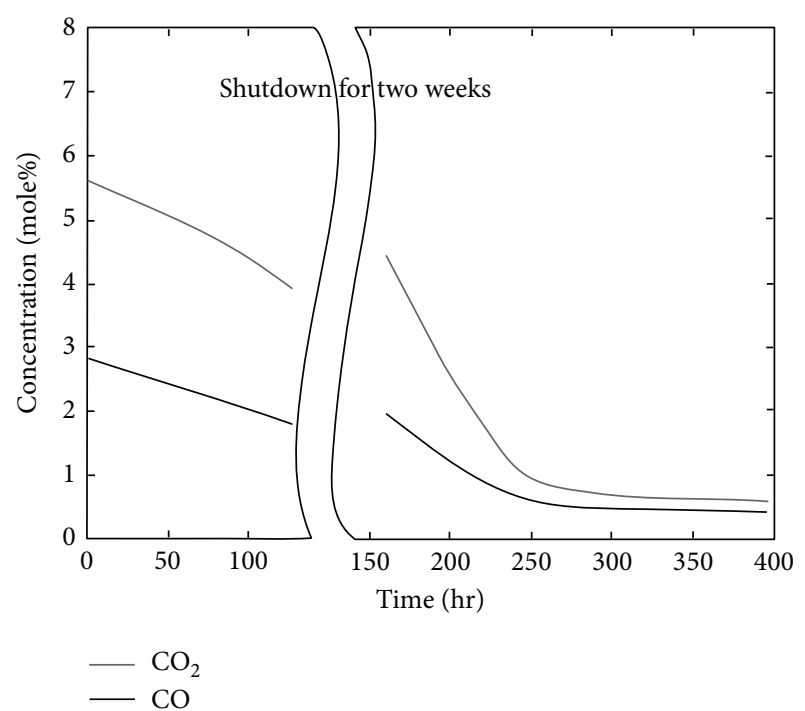

Figure 2: Startup curve for a half-cell stack at $T=600^{\circ} \mathrm{C}, P_{\mathrm{CH}_{4}}=$ $20 \mathrm{kPa}, P_{\mathrm{H}_{2} \mathrm{O}}=59 \mathrm{kPa}, P_{\mathrm{H}_{2}}=4 \mathrm{kPa}$, and $P_{\mathrm{N}_{2}}=36 \mathrm{kPa}$.

steady state after startup and after changes in temperature or hydrogen partial pressure. An example of this is shown in Figure 2. Possible explanation for such a decrease in activity is changes in the anode microstructure, carbon deposition, and poisoning. All experiments were conducted under conditions where carbon formation should not be possible and no signs of carbon formation were observed after the experiments. The dynamic behaviour is ascribed to microstructural changes in the anode; however, it is not possible to conclusively rule out $\mathrm{ppb}$ levels of poisoning. An important note on this dynamic behavior is that if the activation energy is examined without waiting for steady state after each temperature change, the value will be underestimated with a factor 2-3. All measurements reported in this paper are obtained after steady state has been achieved at the relevant temperature.

Figures 3 and 4 show the influence on the reaction rate of varying the inlet gas composition at $650^{\circ} \mathrm{C}$ and $750^{\circ} \mathrm{C}$, respectively. The measurements of the reaction rate dependence on the $\mathrm{CO}$ concentration at $650^{\circ} \mathrm{C}$ were not completed due to problems with the equipment.

The observed reaction order of all species except methane is seen to be close to zero, in agreement with the majority of the expressions reported in the literature [2-15]. A weak dependence on $P_{\mathrm{H}_{2}},-0.2$ at $650^{\circ} \mathrm{C}$ and 0.1 at $750^{\circ} \mathrm{C}$, is observed. This could be due to restructuring of the catalyst. The influence of methane partial pressure has been tested at several temperatures, and the observed rate orders are shown in Table 2. A power law expression was fitted to the measured data using a methane rate order of 0.7. It should be noted that this rate expression is only intended as a direct description of the observed conversions and as such mass transport limitations and temperature gradients have not been taken into account. Such effects will be discussed in the next section. That is, the rate constant is calculated from (3). The change in methane concentration through the cell is
TABLE 2: Measured rate order of $\mathrm{CH}_{4}$ at different temperatures.

\begin{tabular}{lc}
\hline$T\left[{ }^{\circ} \mathrm{C}\right]$ & Reaction order \\
\hline 600 & 0.63 \\
625 & 0.56 \\
650 & 0.75 \\
675 & 0.80 \\
725 & 0.63 \\
750 & 0.65 \\
775 & 0.71 \\
800 & 0.73 \\
\hline
\end{tabular}

taken into account by using a logarithmic mean of the inlet and outlet concentrations, even though this is only accurate when there is a first order dependency:

$$
\begin{aligned}
k= & \left(r_{\mathrm{obs}}\right) \\
& \times\left(A_{\mathrm{ano}} *\left(\frac{P_{\mathrm{CH}_{4} \text {, in }}-P_{\mathrm{CH}_{4}, \text { out }}}{\log \left(P_{\mathrm{CH}_{4}, \mathrm{in}}\right)-\log \left(P_{\mathrm{CH}_{4}, \mathrm{out}}\right)}\right)^{0.7}\right)^{-1},
\end{aligned}
$$

where $r_{\mathrm{obs}}$ is the observed rate and $A_{\text {ano }}$ is the geometric anode area $\left(\approx 23 \mathrm{~cm}^{2}\right)$. An Arrhenius plot of the rate constant for this kinetic expression is shown in Figure 5, resulting in the rate expression in

$$
r=2 \cdot 10^{4} \frac{\mathrm{mole}}{\mathrm{s} \mathrm{m}^{2} \mathrm{~Pa}} \exp \left(\frac{-166.1(\mathrm{~kJ} / \mathrm{mole}) R_{g}}{T}\right) P_{\mathrm{CH}_{4}}^{0.7} .
$$

\section{Predicting the Reaction Rate from Intrinsic Kinetics}

Kinetic measurements in a stack configuration are subject to mass transport limitations and temperature gradients and conditions vary significantly over the cell area. This means that a rate expression obtained on a stack is not necessarily valid for a stack with a different configuration. In detailed models with a complete description of mass and energy transport this problem can be avoided by using intrinsic kinetics. This type of model requires massive computations and as such is not viable for flow sheet models. Here, a simple approach to predicting steam reforming kinetics in a stack from intrinsic kinetics is presented and validated against the stack measurements. The cell/stack is described by the design equation for a packed bed reactor as shown in (5) [16]. The differential equation is solved using ode45 in MATLAB, taking into account the change in gas composition through the stack:

$$
\frac{d X_{\mathrm{CH}_{4}}}{d W_{\text {cat }}}=\frac{r_{\text {eff }}}{N_{\mathrm{CH}_{4}, \text { in }}},
$$




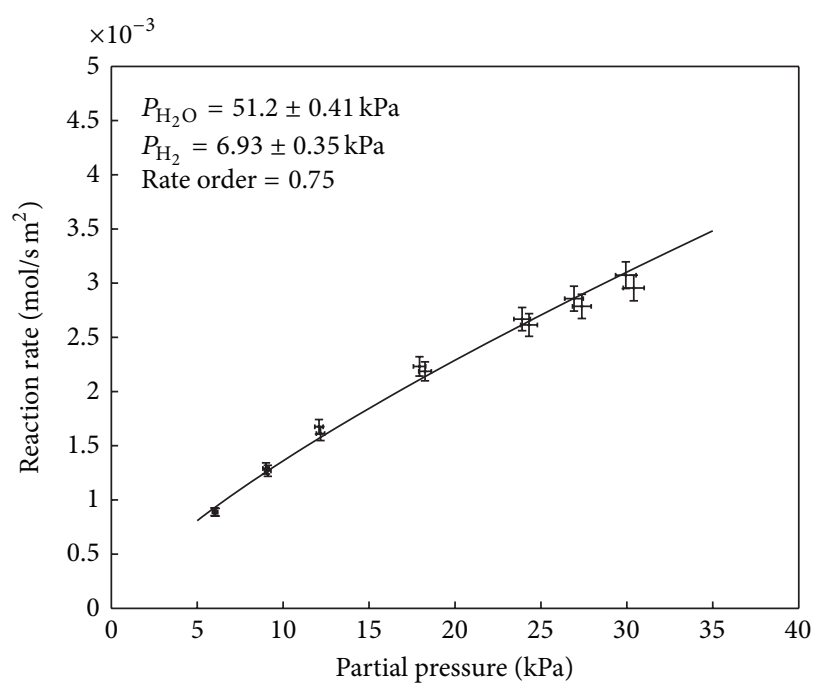

(a) Dependency on $\mathrm{CH}_{4}$

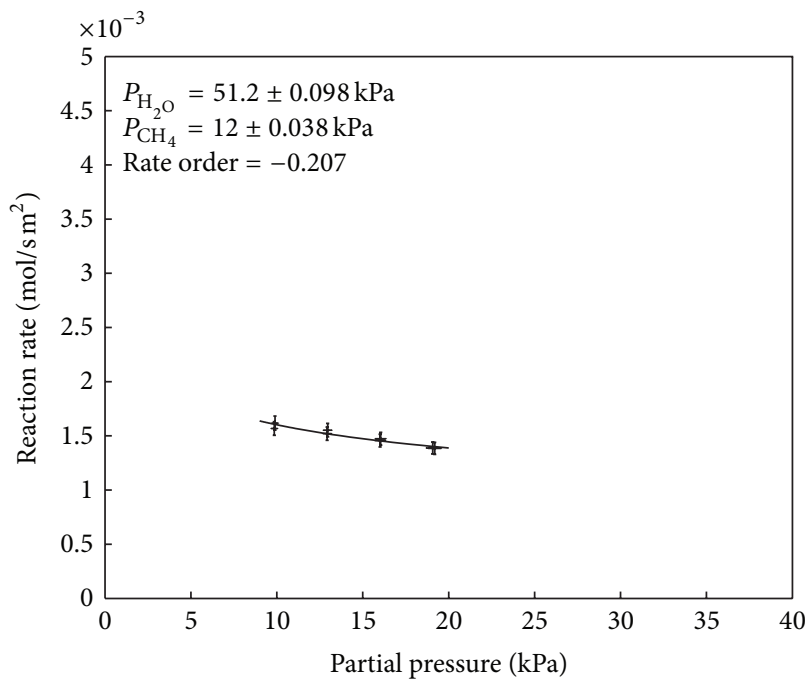

(c) Dependency on $\mathrm{H}_{2}$

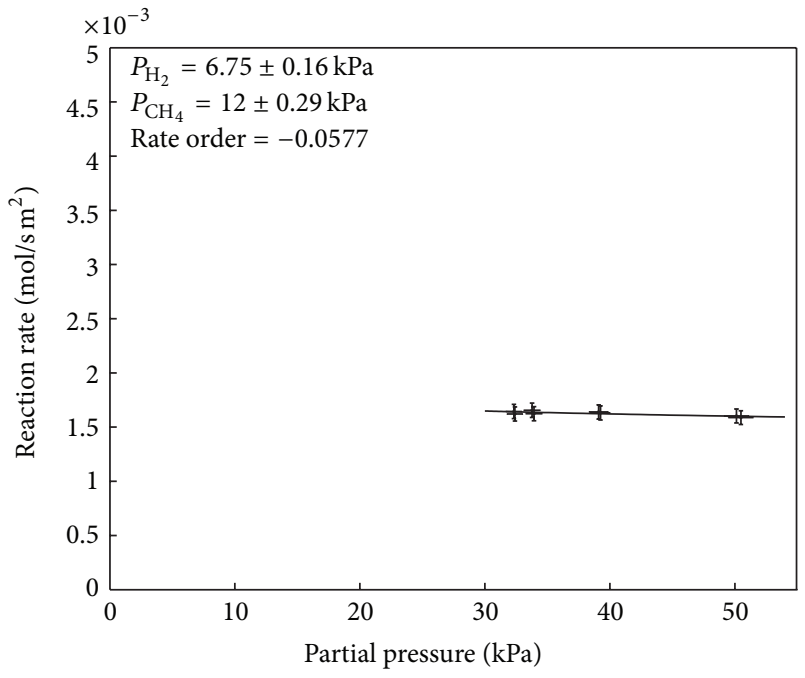

(b) Dependency on $\mathrm{H}_{2} \mathrm{O}$

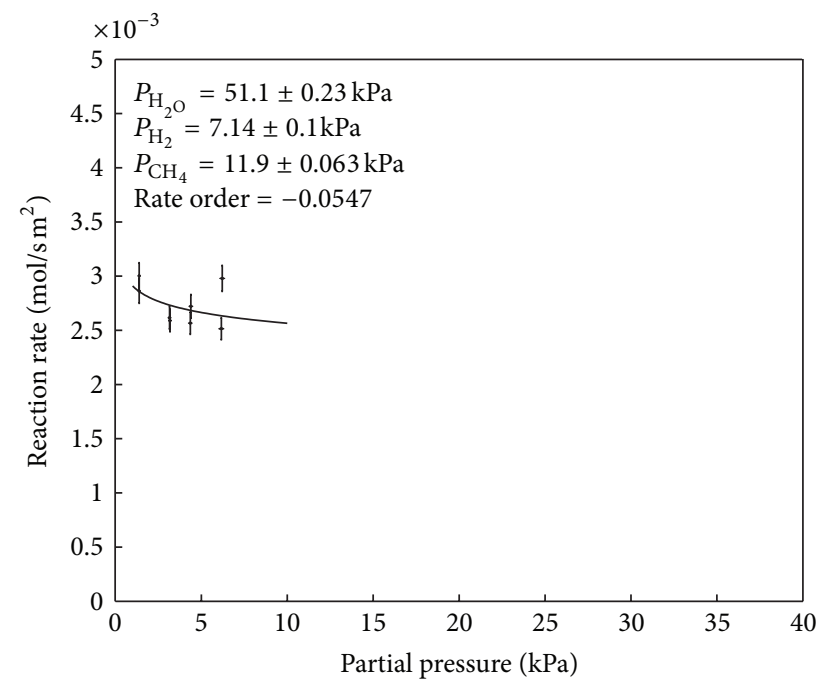

(d) Dependency on $\mathrm{CO}_{2}$

FIGURE 3: Reaction rate of the internal steam reforming as function of the gas concentration of $\mathrm{CH}_{4}, \mathrm{H}_{2} \mathrm{O}, \mathrm{H}_{2}$, and $\mathrm{CO}_{2}$ in a quarter cell stack at $650^{\circ} \mathrm{C}$.

where $X_{\mathrm{CH}_{4}}$ is the degree of conversion of methane, $W_{\text {cat }}$ is the catalyst weight, $N_{\mathrm{CH}_{4} \text {,in }}$ is the molar inlet flow of methane, and $r_{\text {eff }}$ is the effective reaction rate described by

$$
r_{\mathrm{eff}}=\eta * r_{\mathrm{int}}
$$

where $\eta$ describes how big a fraction of the available catalyst material that is being fully used is; that is, an efficiency factor $=1$ corresponds to full usage of the catalyst [17]:

$$
\eta=\frac{\tanh (\phi)}{\phi}
$$

where $\phi$ is the Thiele modulus, which for first order kinetics is

$$
\phi=L \sqrt{\frac{k}{D}}
$$

where $L$ is the anode thickness, $k$ is the rate constant $\left(\mathrm{s}^{-1}\right)$, and $D$ is the effective diffusion coefficient $\left(\mathrm{m}^{2} \mathrm{~s}^{-1}\right)$ of methane. The gas composition is a multicomponent mixture and the pore size of the anode support $(0.4-1 \mu \mathrm{m})$ is in the range where Knudsen diffusion must be taken into account. For this case it is not trivial to estimate the effective diffusion coefficient. We will in the analysis of the data first treat it as a fitting parameter. The expression used here for determining $\eta$ is valid for systems where pore diffusion is dominant, that 


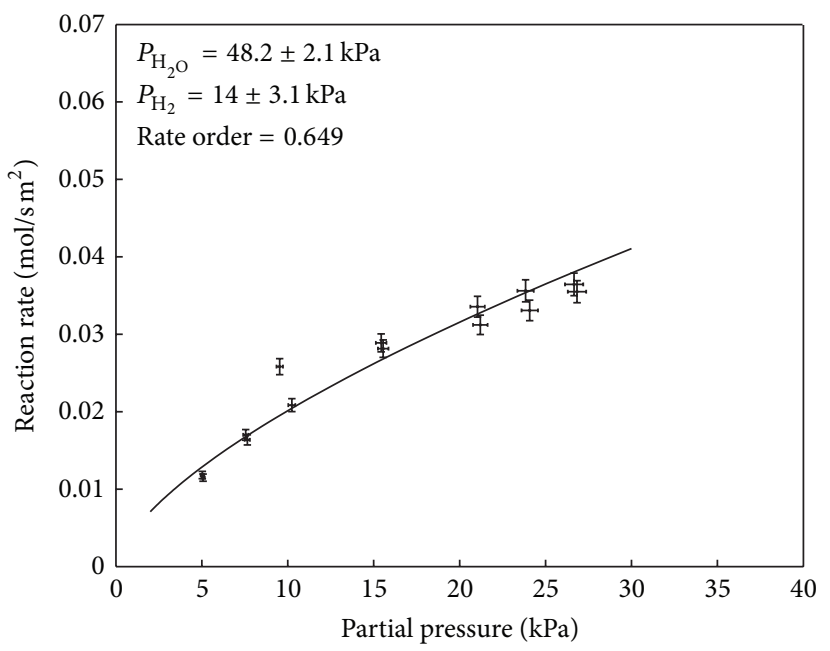

(a) Dependency on $\mathrm{CH}_{4}$

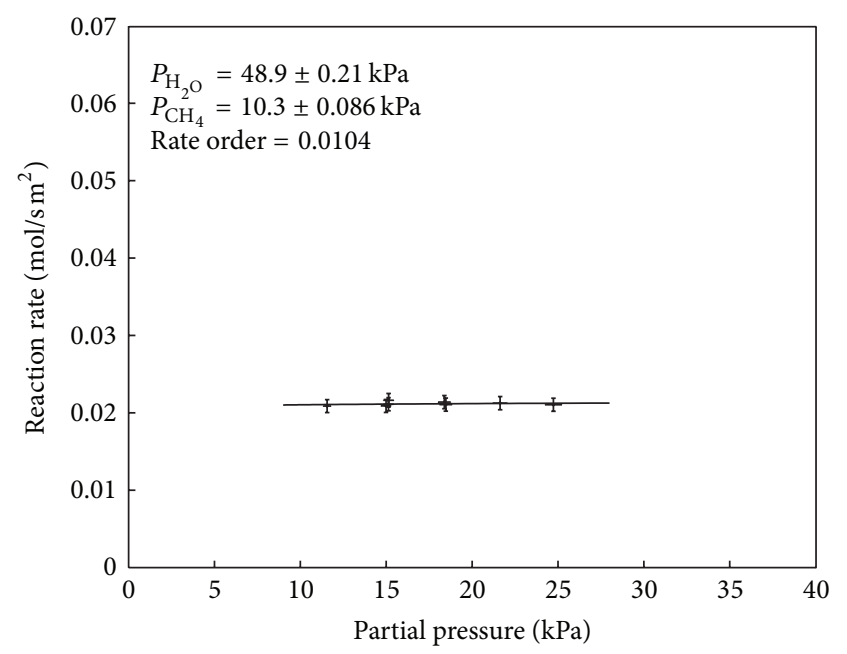

(c) Dependency on $\mathrm{H}_{2}$

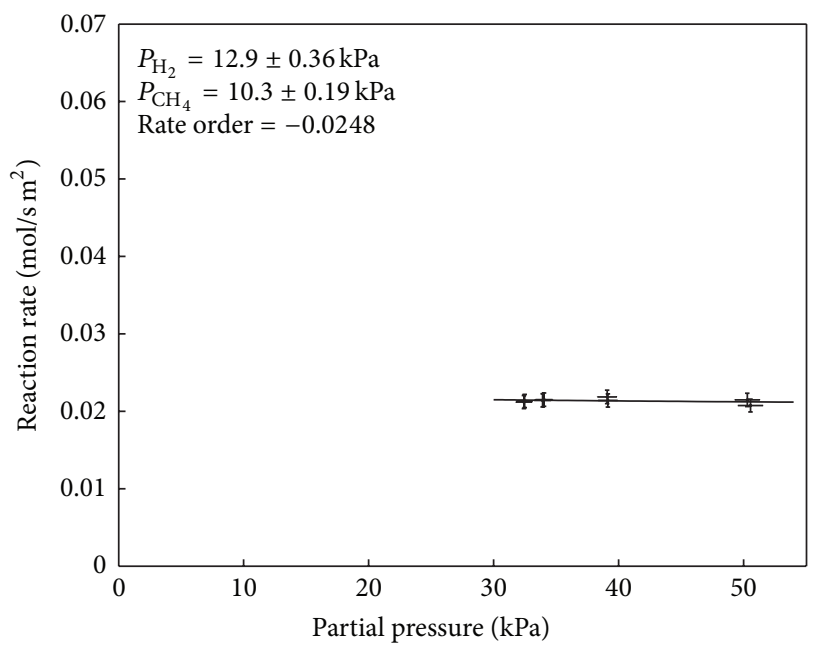

(b) Dependency on $\mathrm{H}_{2} \mathrm{O}$

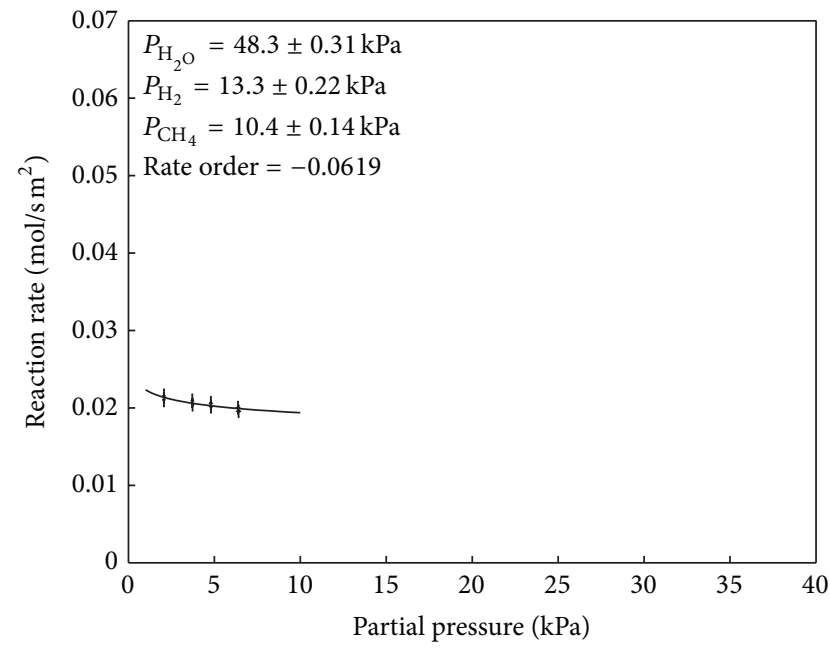

(d) Dependency on CO

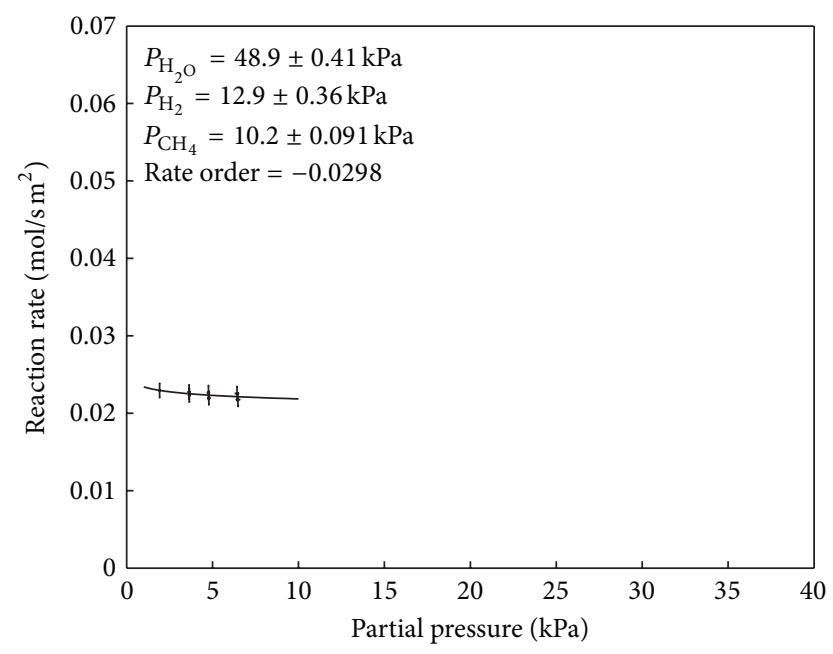

(e) Dependency on $\mathrm{CO}_{2}$

FIGURE 4: Corresponding measured rates and dependencies of the different gas species over the quarter cell stack at $750^{\circ} \mathrm{C}$. 


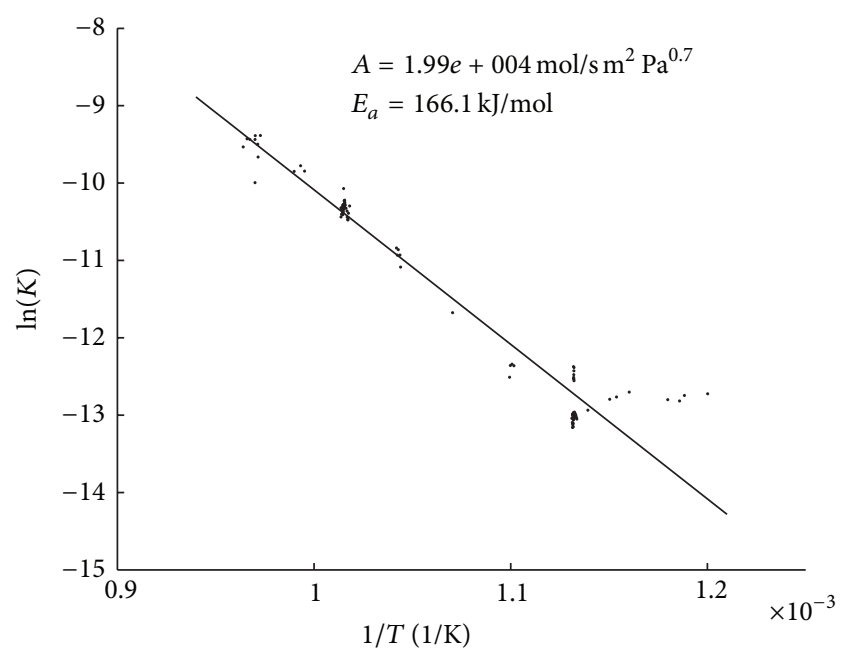

FIGURE 5: Arrhenius plot for measured rate constants on the quarter cell stack.

is, intermediate values of $\phi$. At high and low values of $\phi$ other estimations should be used.

The intrinsic rate $\left(r_{\text {int }}\right)$ is calculated from an expression obtained in a plug-flow reactor under differential conversion and without mass transfer limitations. The expression is shown in

$$
\begin{aligned}
& r_{\text {int }} \\
& =\left(100 \frac{\mathrm{mole}}{\mathrm{gs} \mathrm{Pa}} \exp \left(\frac{-195(\mathrm{~kJ} / \mathrm{mole})}{R T}\right)\right. \\
& \left.\quad \times P_{\mathrm{CH}_{4}}\left(1-\frac{Q_{\mathrm{sr}}}{K_{\mathrm{sr}}}\right)\right) \\
& \times\left(\left(1+4.6 \cdot 10^{-7} \mathrm{~Pa}^{-1} \exp \left(\frac{32(\mathrm{~kJ} / \text { mole })}{R T}\right) P_{\mathrm{CO}}\right)^{2}\right)^{-1} .
\end{aligned}
$$

The majority of the kinetic expressions reported in the literature for steam reforming over Ni-YSZ report an activation energy in the range $58-135 \mathrm{~kJ} / \mathrm{mol}[4,13-15,20-22]$, and only a few report values around $200 \mathrm{~kJ} / \mathrm{mol}$ [23-25].

The high activation energy both in (9) and (4) is a result of waiting for the slow approach to steady state at each temperature, which has not been reported in the previous studies. The expressions presented here are consequently not a good representation of the steam reforming rate in a stack just after startup or a temperature change. Instead they describe the reforming rate in a stack operating at steady state for long periods of time.

Figure 6 shows a comparison of the measured conversion in the "stack" experiment and the conversion predicted from the expression of the intrinsic kinetics (9) "corrected" for mass transfer limitations (6)-(8) and differentiated across the anode (5). Figure 6(a) shows the entire range of obtained values, while Figure 6(b) shows a zoom at low conversion.
The line in the figures correspond to ideal fit between the measured value and the predicted value.

Considering the simplicity of the model, it gives a surprisingly good agreement of the measured conversion in the stack and the estimate deduced from the intrinsic kinetics via the model. Note that the only inputs are the inlet gas composition, the effective diffusion coefficient, and the temperature. Best agreement is observed for an effective diffusion coefficient of $10^{-5} \mathrm{~m}^{2} \mathrm{~s}^{-1}$ (note that any temperature dependence of the diffusion coefficient has been neglected). It can furthermore be seen from the figures that the major deviations are at low conversion while higher conversions result in a better fit. The measurements that deviate most from the model in Figure 6(b) are with methane concentration changes at $675^{\circ} \mathrm{C}$ (four points overestimated by model) and $625^{\circ} \mathrm{C}$ (four points underestimated by model). It is also these four measurements at $625^{\circ} \mathrm{C}$ that deviate from the trend in the Arrhenius plot in Figure 5. This deviance could be an indication that the surface structure at low temperatures is substantially different from the structure in the majority of the measurements presented here. However, the deviation does not seem to be systematic and for the scope of this study it is ascribed to experimental uncertainty.

The value of the diffusion coefficient that gave the best description was $10^{-5} \mathrm{~m}^{2} \mathrm{~s}^{-1}$ resulting in an efficiency factor close to 1 at $600^{\circ} \mathrm{C}$ and $\approx 0.5$ at $800^{\circ} \mathrm{C}$. This value corresponds to 0.04 times the binary diffusion coefficient of a steam/methane gas mixture at $750^{\circ} \mathrm{C}$, calculated as described in appendix. The strong reduction as compared to the free gas value is due to the hindering effect of the anode support. Assuming a porosity of 30\% and a tortuosity of 3 a reduction of the binary gas diffusion of a factor of 10 should be expected. Moreover the effective diffusion coefficient is further reduced due to a small size of the pores. Hence, a reduction by a factor of 20 does not seem unfeasible. In a study of mass transport limitations on the electrochemical conversion of hydrogen in a similar but slightly less porous anode structure, Hendriksen et al. [26] reported values of the effective diffusion coefficient on the order of $0.5-1 \%$ of the binary diffusion coefficients.

The results are given high credibility from the fact that the measurements can be correlated with measurements from a plug-flow reactor through a simple description of the expected mass transport in the stack.

\section{Conclusion}

The rate of methane steam reforming over an SOFC NiYSZ anode has been measured in the temperature range $600-800^{\circ} \mathrm{C}$ and with variations in the partial pressure of all reactants and products. The activity was observed to have a long-term dynamic behavior. Furthermore, a simple method for predicting methane conversion in a stack from an intrinsic expression was presented. The method was validated against the quarter stack measurements and was found to give a surprisingly good representation of the observed methane conversion. The simplicity of this method makes it ideal for simple SOFC stack models, for flow sheeting purposes. 


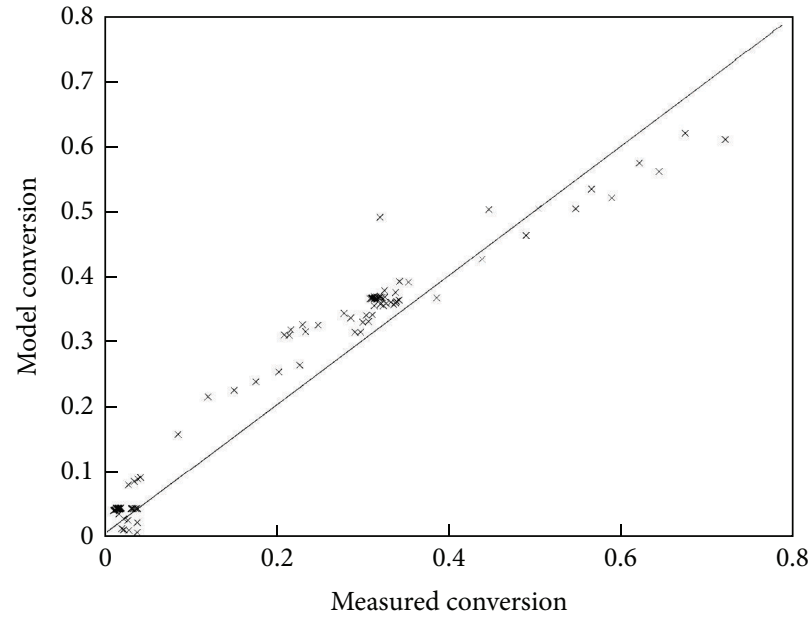

(a) Results with measured temperature

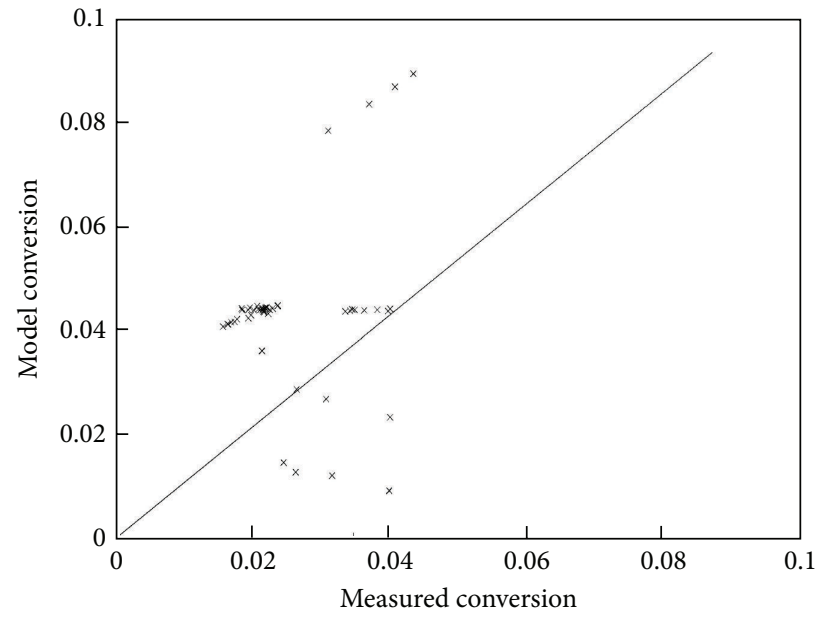

(b) Representation of the data in Figure 6(a) only at low conversion

FIGURE 6: Comparison of measured conversion and the conversion predicted by the model using data from a plug-flow reactor.

TABLE 3: Constants used for determining the binary diffusion coefficients $[18,19]$.

\begin{tabular}{lccc}
\hline & $\sigma$ & $\epsilon / \mathrm{k}$ & $M$ \\
& $\AA$ & $\mathrm{K}$ & $\mathrm{g} / \mathrm{mol}$ \\
\hline $\mathrm{O}_{2}$ & 3.433 & 113 & 31.999 \\
$\mathrm{~N}_{2}$ & 3.667 & 99.8 & 28.013 \\
$\mathrm{H}_{2}$ & 2.915 & 38 & 2.016 \\
$\mathrm{H}_{2} \mathrm{O}$ & 2.641 & 809.1 & 18.016 \\
$\mathrm{CO}$ & 3.590 & 110 & 28.010 \\
$\mathrm{CO}_{2}$ & 3.996 & 190 & 44.010 \\
$\mathrm{CH}_{4}$ & 3.780 & 154 & 16.040 \\
\hline
\end{tabular}

\section{Appendix}

\section{Estimation of Diffusion Coefficient}

The Chapman-Enskog expression, (A.1), is used to determine binary diffusion coefficients $\left(D_{i j}\right)$ :

$$
D_{i j}=0.0018583 \sqrt{T^{3}\left(\frac{1}{M_{i}}+\frac{1}{M_{j}}\right)} \frac{1}{P \sigma_{i j}^{2} \Omega_{D_{i j}}},
$$

where $M$ is the molar mass of the denoted species and $\Omega$ is the dimensionless collision integral, which is a function of the dimensionless temperature, $\kappa T / \epsilon_{i j}$. The parameters $\sigma$ and $\epsilon / \kappa$ can be found as tabulated values for each species, and the value for each pair of species can be estimated by [18]

$$
\begin{aligned}
\sigma_{i j} & =\frac{\sigma_{i}+\sigma_{j}}{2} \\
\epsilon_{i j} & =\sqrt{\epsilon_{i} \epsilon_{j}} .
\end{aligned}
$$

The tabulated values of $\sigma$ and $\epsilon$ that are used in this project are shown in Table 3.
Equation (A.4) given by Reid et al. [19] is used to calculate $\Omega_{D_{i j}}$;

$$
\begin{gathered}
y=x^{4}+4 \\
=\left(x^{2}+2\right)^{2}-4 x^{2} \\
\leq\left(x^{2}+2\right)^{2} \\
\Omega_{D_{i j}}=\frac{A}{\left(T^{*}\right)^{B}}+\frac{C}{\exp \left(D T^{*}\right)}+\frac{E}{\exp \left(F T^{*}\right)}+\frac{G}{\exp \left(H T^{*}\right)},
\end{gathered}
$$

where $T^{*}=\kappa T / \epsilon_{i j}$ is the dimensionless temperature and the constants $A-H$ are given below:

$$
\begin{aligned}
& A=1.06036, \\
& B=0.15610, \\
& C=0.19300, \\
& D=0.47635, \\
& E=1.03587, \\
& F=1.52996, \\
& G=1.76474, \\
& H=3.89411 .
\end{aligned}
$$

The method described here should give the binary diffusion coefficients within $10 \%$.

\section{Conflict of Interests}

The authors declare that there is no conflict of interests regarding the publication of this paper. 


\section{References}

[1] J. R. Rostrup-Nielsen, J. Sehested, and J. K. Nørskov, "Hydrogen and synthesis gas by steam- and C02 reforming," Advances in Catalysis, vol. 47, pp. 65-139, 2002.

[2] D. Mogensen, J.-D. Grunwaldt, P. V. Hendriksen, K. DamJohansen, and J. U. Nielsen, "Internal steam reforming in solid oxide fuel cells: status and opportunities of kinetic studies and their impact on modelling," Journal of Power Sources, vol. 196, no. 1, pp. 25-38, 2011.

[3] P. Hendriksen, "Model studies of internal steam reforming in SOFC stacks," in Proceedings of the 5th International Symposium on Solid Oxide Fuel Cells (SOFC '97), pp. 1319-1328, 1997.

[4] H. Timmermann, W. Sawady, R. Reimert, and E. Ivers-Tiffée, "Kinetics of (reversible) internal reforming of methane in solid oxide fuel cells under stationary and APU conditions," Journal of Power Sources, vol. 195, no. 1, pp. 214-222, 2010.

[5] T. X. Ho, P. Kosinski, A. C. Hoffmann, and A. Vik, "Effects of heat sources on the performance of a planar solid oxide fuel cell," International Journal of Hydrogen Energy, vol. 35, no. 9, pp. 4276-4284, 2010.

[6] N. Akhtar, S. P. Decent, and K. Kendall, "Numerical modelling of methane-powered micro-tubular, single-chamber solid oxide fuel cell," Journal of Power Sources, vol. 195, no. 23, pp. 77967807, 2010.

[7] T. F. Petersen, N. Houbak, and B. Elmegaard, "A zerodimensional model of a 2nd generation planar SOFC using calibrated parameters," International Journal of Thermodynamics, vol. 9, no. 4, pp. 161-169, 2006.

[8] S. H. Chan, H. K. Ho, and Y. Tian, "Multi-level modeling of SOFC-gas turbine hybrid system," International Journal of Hydrogen Energy, vol. 28, no. 8, pp. 889-900, 2003.

[9] M. Sucipta, S. Kimijima, and K. Suzuki, "Performance analysis of the SOFC-MGT hybrid system with gasified biomass fuel," Journal of Power Sources, vol. 174, no. 1, pp. 124-135, 2007.

[10] K. Nikooyeh, A. A. Jeje, and J. M. Hill, "3D modeling of anodesupported planar SOFC with internal reforming of methane," Journal of Power Sources, vol. 171, no. 2, pp. 601-609, 2007.

[11] F. P. Nagel, T. J. Schildhauer, S. M. A. Biollaz, and S. Stucki, "Charge, mass and heat transfer interactions in solid oxide fuel cells operated with different fuel gases-a sensitivity analysis," Journal of Power Sources, vol. 184, no. 1, pp. 129-142, 2008.

[12] http://www.fuelcon.com.

[13] D. L. King, J. J. Strohm, X. Wang et al., "Effect of nickel microstructure on methane steam-reforming activity of Ni-YSZ cermet anode catalyst," Journal of Catalysis, vol. 258, no. 2, pp. 356-365, 2008.

[14] M. Boder and R. Dittmeyer, "Catalytic modification of conventional SOFC anodes with a view to reducing their activity for direct internal reforming of natural gas," Journal of Power Sources, vol. 155, no. 1, pp. 13-22, 2006.

[15] E. Achenbach and E. Riensche, "Methane/steam reforming kinetics for solid oxide fuel cells," Journal of Power Sources, vol. 52, no. 2, pp. 283-288, 1994.

[16] S. Fogler, Elements of Chemical Reaction Engineering, Prentice Hall, New York, NY, USA, 1999.

[17] I. Chorkendorff and J. Niemantsverdriet, Concepts of Modern Catalysis and Kinetics, Wiley-VCH, Weinheim, Germany.

[18] R. Bird, W. Stewart, and E. Lightfoot, Transport Phenomena, John Wiley \& Sons, New York, NY, USA, 2nd edition, 2002.
[19] R. Reid, J. Prausnitz, and B. Poling, The Properties of Gases and Liquids, McGraw-Hill, New York, NY, USA, 5th edition, 2001.

[20] A. L. Lee, R. F. Zabransky, and W. J. Huber, "Internal reforming development for solid oxide fuel cells," Industrials and Engineering Chemistry Research, vol. 29, no. 5, pp. 766-773, 1990.

[21] R. Odegard, E. Johnsen, and H. Karoliussen, "Methane reforming on Ni/zirconia SOFC anodes," in Proceedings of the 4th International Symposium on Solid Oxide Fuel Cells (SOFC '95), pp. 810-819, 1995.

[22] K. Ahmed and K. Foger, "Kinetics of internal steam reforming of methane on Ni/YSZ-based anodes for solid oxide fuel cells," Catalysis Today, vol. 63, no. 2-4, pp. 479-487, 2000.

[23] S. Bebelis, A. Zeritis, C. Tiropani, and S. G. Neophytides, "Intrinsic kinetics of internal steam reforming of $\mathrm{CH} 4$ over a Ni-YSZ-cermet catalyst-electrode," Industrial and Engineering Chemistry Research, vol. 39, no. 12, pp. 4920-4927, 2000.

[24] H. Yakabe, T. Ogiwara, M. Hishinuma, and I. Yasuda, "3-D model calculation for planar SOFC," Journal of Power Sources, vol. 102, no. 1-2, pp. 144-154, 2001.

[25] R. Leinfelder, Reaktionskinetische Untersuchung zur MethanDampf-Reformierung und Shift-Reaktion an Anoden oxidkeramischer Brennstoffzellen [Ph.D. thesis], Der Technischen Fakultat der Universitat Erlangen-Nurnberg, 2004.

[26] P. Hendriksen, S. Koch, M. Mogensen, Y. L. Liu, and P. H. Larsen, "Break down of losses in thin electrolyte SOFCs," in Proceedings of the 8th International Symposium on Solid Oxide Fuel Cells (SOFC '20), Paris, France, April-May 2003. 

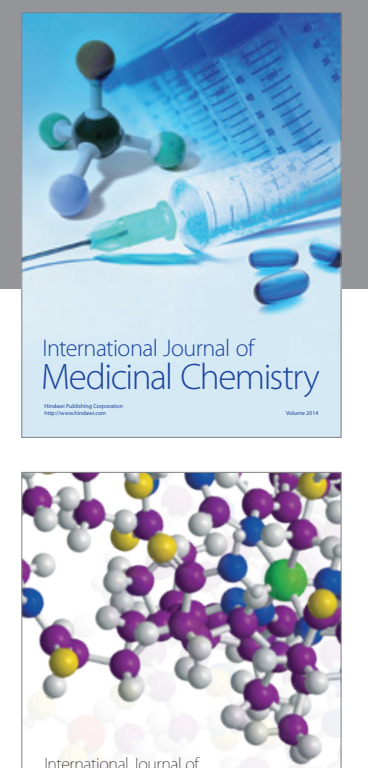

\section{Carbohydrate} Chemistry

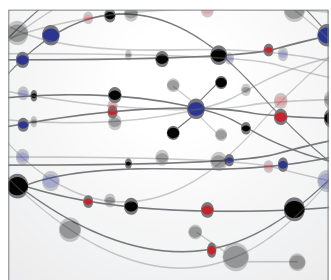

The Scientific World Journal
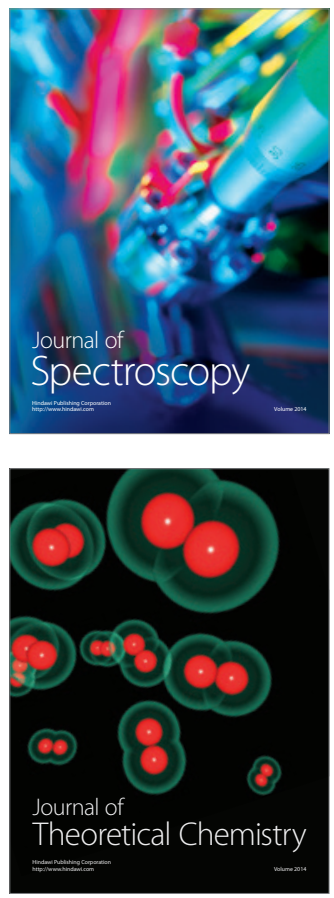
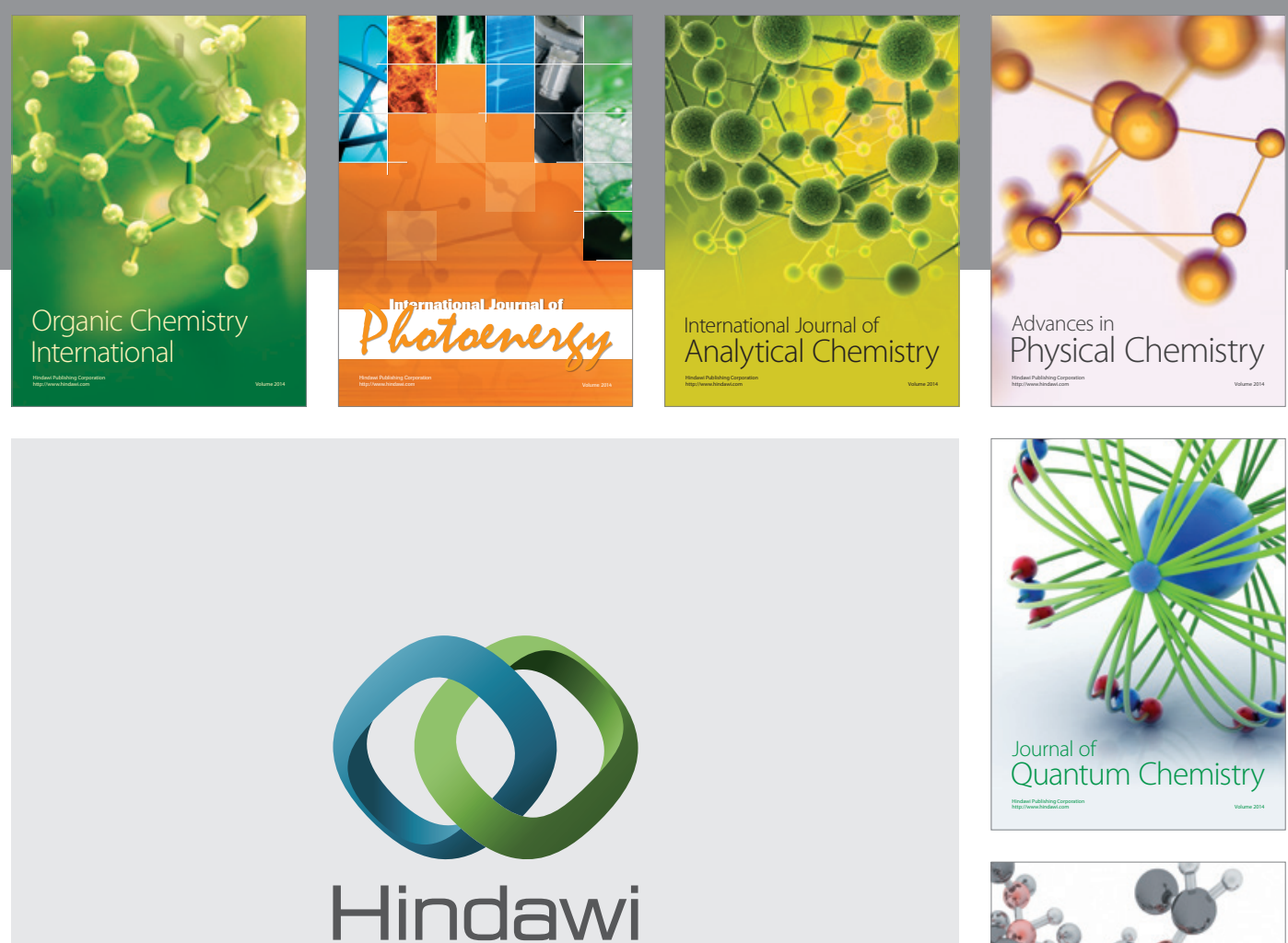

Submit your manuscripts at

http://www.hindawi.com

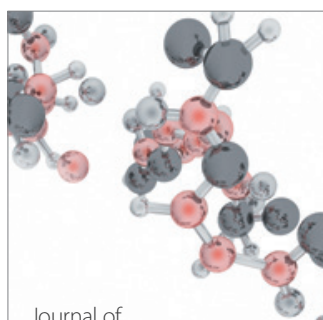

Analytical Methods

in Chemistry

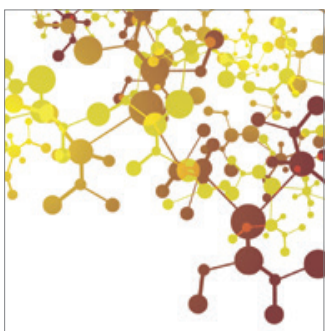

Journal of

Applied Chemistry

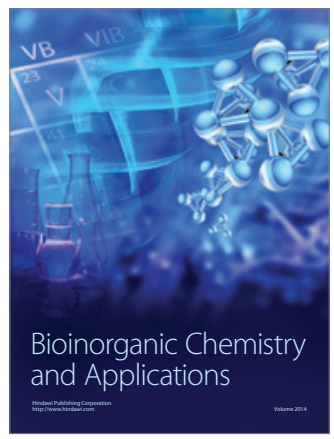

Inorganic Chemistry
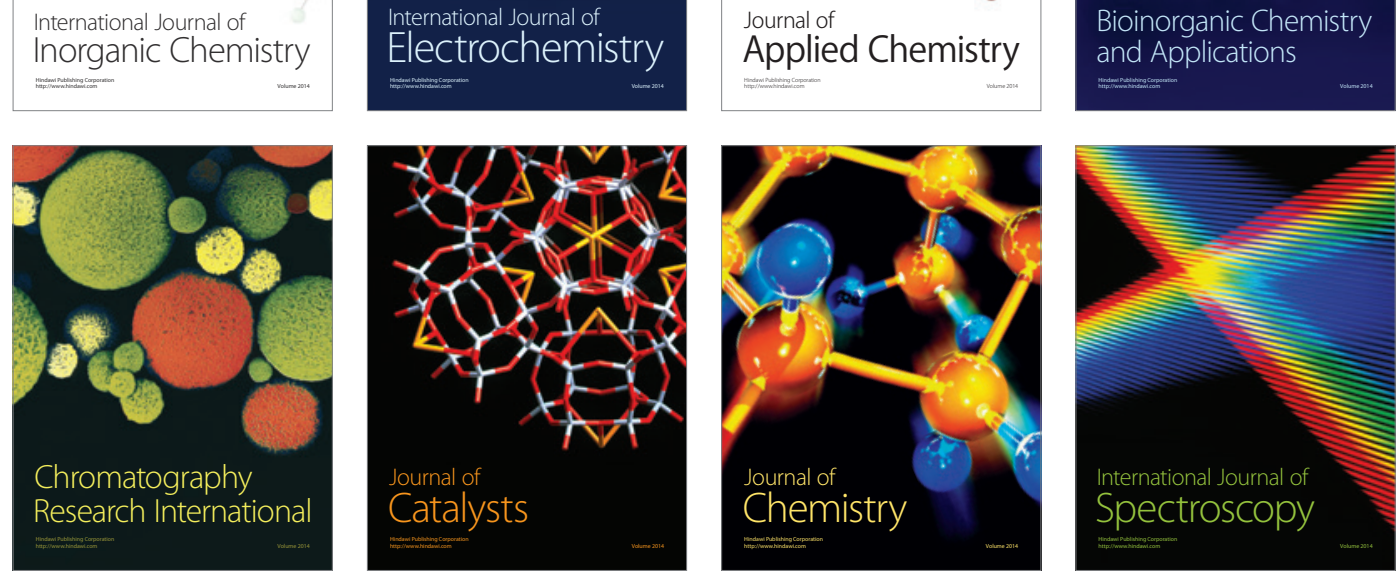